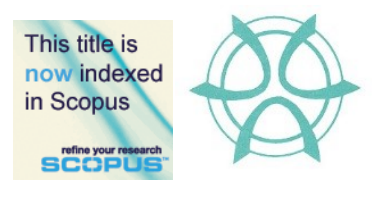

PLANNING MALAYSIA:

Journal of the Malaysian Institute of Planners

VOLUME 19 ISSUE 1 (2021), Page 53 - 64

\title{
ASSESSMENT ON THE IMPLEMENTATION OF PLOT RATIO AS A DEVELOPMENT CONTROL TOOL IN GEORGE TOWN, PENANG
}

\author{
Syafiqah Humairah Abd Razak', Izuandi Yin ${ }^{2}$ \\ ${ }^{1,2}$ School of Housing Building and Planning \\ UNIVERSITI SAINS MALAYSIA
}

\begin{abstract}
This paper investigates the changes of buildings to what extent the regulations related to plot ratio are implemented in the city of George Town, Penang, give impact on land use distribution. This study used a quantitative method by conducting field observations to identify building heights in the city of George Town, which was divided into two segments of the road. Then, GIS software was also used as one of the instruments to map the compliance analysis on study area in the city for the development control tool. The results show that quantitatively, the buildings along Jalan Dato Keramat that have been monopolised by residential activities acquire a higher building height and the maximum of plot ratio caps. There is only a small portion in Jalan Gurdwara that complies with the plot ratio limit. However, the characteristics of the area were determined by several parameters, such as building height, zoning land use activities, and building conformity. Thus, more detailed regulations regarding the changes in shape and plot ratio cap according to zoning activities on the exact location and activities are highly required.
\end{abstract}

Keywords: Plot Ratio, Development Control

2 Lecturer at Universiti Sains Malaysia. Email: izuandi.yin@usm.my 
Syafiqah Humairah Abd Razak, Izuandi Yin

Assessment on The Implementation of Plot Ratio as A Development Control Tool in George Town, Penang

\section{INTRODUCTION}

George Town is among the greatest deal of attractions throughout the world due to its shape of land use activities, which are more focused on commercial activities with the support of industrial activities (Samat et al., 2014). The location for this study is between $4^{\circ} 50^{\prime} \mathrm{N}$ and $5^{\circ} 52^{\prime} \mathrm{N}$ (latitude), and $100^{\circ} 10^{\prime} \mathrm{E}$ (longitude) and $100^{\circ} 51^{\prime} \mathrm{E}$, in the north-west coast of Peninsular Malaysia (Narimah \& Amirul, 2019). Therefore, with all these great deals of attraction, it indirectly helps to attract more people to migrate from rural to urban areas in pursuit of a greater standard of life by facilitating services and urban activities (Deng et al., 2009). Consequently, this has led to an increase of urban population density as George Town is the capital of Penang and located in the north-eastern region. The city holds the highest future population distribution by district in the next ten years, which is 85,200 of the increment from the year 2020 to the year 2030 (Draft Penang Structure Plan 2030) compared to the other three districts in the south-west region of the island: North Seberang Perai (SPU), South Seberang Perai (SPS), and Central Seberang Perai (SPT). Recently, an urban area in the city of George Town is facing scarcity of land due to the migration and increase in population growth. Hence, new development progress by developers and private sectors have been competing to fulfil the population's high demand on the engagement of numerous community facilities and resources, including residential, educational, healthcare, entertainment, and shopping to be occupied with the highest volume of occupancy. This has resulted in various negative external impact, such as pressure on infrastructure used. The importance of land conversion and land use distribution on plot ratio approval plays an important role in controlling the development. The allocation in the maximum limit of plot ratio gives a greater purpose to every property which leads to long-term planning control. Due to the land scarcity, the land and property value are increasing due to the demand for property use in the city centre, but it requires good compliance of development towards government policies and planning standards. Besides that, Joshi \& Kono (2009) explained in their research on maximum plot ratio regulation which was widely used. In their research, they stated that to control population density for reducing population externalities, a maximum limit on plot ratio (or building size) must be set. Firstly, with the implementation of a minimum plot ratio rule to raise population density for this purpose; it sets a minimum building size. Although some measures owe to the 3 complexities of the regulatory structure and the absence of reliable details for every lot of land (Gao \& Asami, 2006), it is difficult to grab the actual value of limiting property use. Neither the zoning plot ratio nor the actual plot ratio correlates to the highest allowable plot ratio of lots so far as some researchers' analyses have added nothing to debates on land use limits, as they have only used the zoning plot ratio or the actual lot plot ratio as a possible property determinant. On the other hand, some of the previous research studies show 3D spatial analysis were used as the 
research instruments to solve some of the issues in urban development. However, only a few studies have emphasised the issues on development plot ratio control regarding to what extent the regulations related to plot ratio are implemented in the city of George Town, Penang, give impact on land use distribution, specifically in Malaysia compared to the other countries who have at least discussed the research studies conducted that are nearly related with the research topic of this study. So, in this paper, the impacts on land use distribution with the usage of planning standard/guideline plot ratio toward monitoring the development of plot ratio controls in George Town, Penang, have been investigated with the surmount of data collection problems found in current studies. Consequently, the study of interest will focus on the research of investigating compliance analysis on plot ratio at a specific location, George Town Study Area, chosen by using GIS analysis technology through the overlay technique.

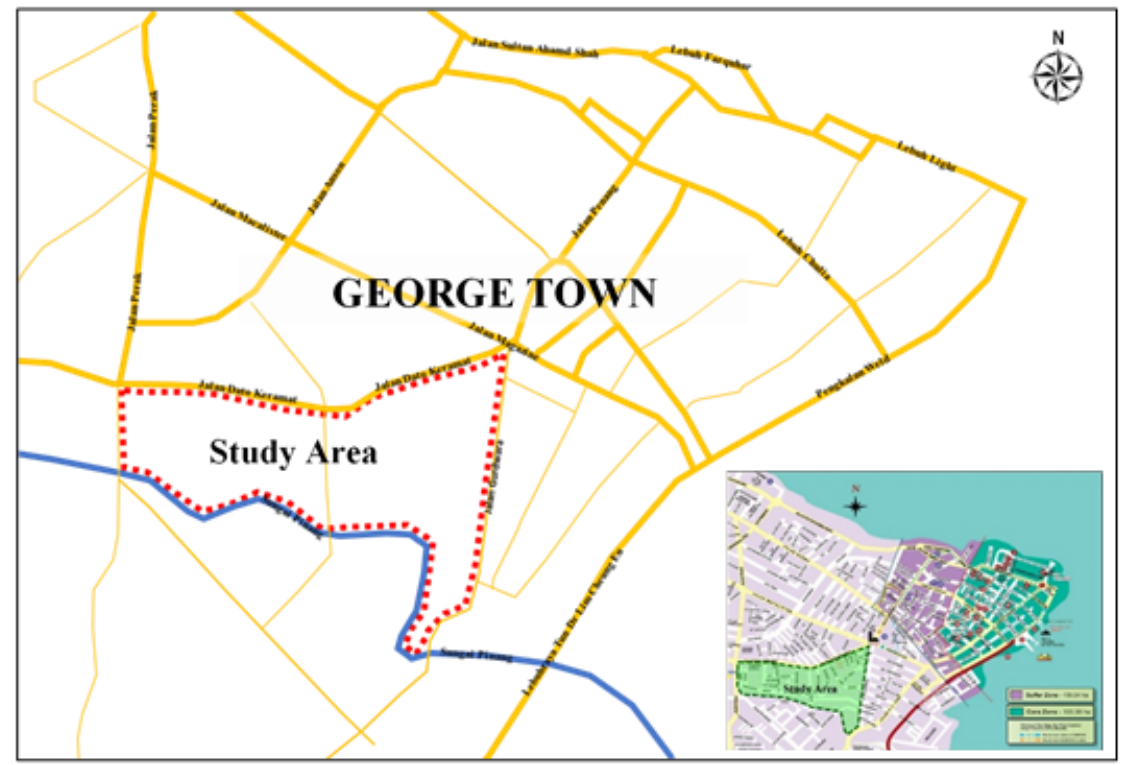

Figure 1: Study area (George Town, Penang) year 2020

\section{PROBLEM STATEMENT}

Significant problems in this research study are in equilibrium allocation of land uses, such as imbalance of building skylines in the city of George Town has led to increase population density. As stated by World Bank (2015), it indicates that the proportion of George Town's built-up area reserved for residential usage is greater than that of Kuala Lumpur and Johor Bahru (43\% opposed to $31 \%$ and 30 $\%$, respectively). Therefore, George Town has passed through speeding up urbanisation and the number of urban populations. Even though Kuala Lumpur's 
Syafiqah Humairah Abd Razak, Izuandi Yin

Assessment on The Implementation of Plot Ratio as A Development Control Tool in George Town, Penang

urban population is the largest in Malaysia, Penang's population density is the highest in Malaysia despite its limited metropolitan region. Since the city of George Town is comparatively limited, it is impossible to account for a significant number of urban regions because of the strong growth rate and population migration due to the growing number of land use activities attraction, thus it is facing critical challenges in terms of land supply. Besides that, increasing demand in various urban amenities engagement and services encourages contact between residents and different urban facilities and services, including market force and job opportunities. As mentioned by Izuandi et al. (2019), shopping, healthcare, and entertainment conduct advancement towards new growth. On the other side, this influx of residents raises the effect on different externalities, such as road congestion, pressure on public infrastructure; sound emissions will also influence other pollutants like emission from the atmosphere. Besides that, Hamdan Abdul Majeed (2012) highlighted that George Town has been branded as a UNESCO World Heritage Site since 2008, which makes the city of George Town guaranteed on several benefits, especially in the field of tourism growth and destination marketing (Lai \& Ooi, 2015). Therefore, these factors contribute to the increase in development cost and property prices. Bertaud \& Brueckner (2005) mentioned in their study that the better the characteristics of the location, the higher the value of market demand. So, it can be used as the push factor for developers as well as private sectors for attracting to develop further growth in a built-up area with high density in George Town with an increase of plot ratio, for gaining their profits. On the other hand, the balance between residential or office space supply and demand needs to be established, considering that there are several vacancies and they are unable to locate the best occupants at the moment. This is attributed to the higher land valuation, attributable to the vast amount of unsold assets due to the discrepancy between the current launch rates and the availability of the household. So, it will open up the opportunity for foreign investors to invest in the city of George Town, which may be harmful to the local economy if they are monopolising the future economic market. The local authority plays a major role in fulfilling its responsibilities in the establishment and preparation of a development plan strategy by drawing up a master plan to track, coordinate, control, and plan development land use in conjunction with buildings in its specific area of authority and plot ratio approvals. These are important as the local authority acts as a controller in balancing between the population of people and the several urban services and amenities, as these wisely monitor Malaysia's development direction that would contribute to improved quality of living and the suitability to achieve long-term competitiveness in the industry.

\section{RESEARCH QUESTION}

Focus on the development control tool of plot ratio in George Town City Centre: 
i. What is the constructed plot ratio allowed in George Town to control the development?

ii. How can the relation between constructed plot ratio by zoning land use activities contribute to the development control?

iii. How to analyse the zoning land use and plot ratio of George Town in defining the compliance with development control?

\section{PURPOSE OF THE STUDY}

The study on monitoring the development control in George Town area by measuring the plot ratio and land use activity. The objectives that need to be achieved in this study are:

i. To identify the plot ratio allocated in the George Town area in controlling the development.

ii. To investigate the compliance of plot ratio with the given planning standards with the physical skyline of George Town.

iii. To determine the statistical value of the existing plot ratio in the compliance and zoning analysis towards monitoring the development control in George Town.

\section{RESEARCH METHODS}

The usage of secondary data was collected from the local authority departments related to development control in George Town, Pulau Pinang, such as PLANMalaysia Pulau Pinang, Majlis Bandaraya Pulau Pinang (MBPP), and also Penang Gis (PEGIS). These secondary data helped in providing the actual plot ratio on study area through the laws used by city councils to enact construction and control land, buildings, and services usage through a program in land use and building-ratio control. The guidelines used in the design of land use of a region are laid out in the comprehensive spatial planning of the community, which involves the zoning system and the decision on the development scale in the form of a plot ratio. This is done by using the method implemented by Izuandi $\&$ Jamalunlaili (2020) to find the result for plinth area and level of the building during observation finalise the built-up area for every lot. Finally, the statistical value of existing plot ratio for development control of study area in George Town, Penang, could be determined after analysing and interpreting data using the technique applied to the plot ratio by calculating the mathematical relationship between the total floor area of the building and that of land area as shown below. Thus, the findings from the tabulated data could be examined for any future suggestions and recommendations.

Plot Ratio $=\underline{\text { Total Floor Area }}$

Land Area 


\section{FINDINGS}

\section{i.The Implementation of Plot Ratio as a Development Control Tool}
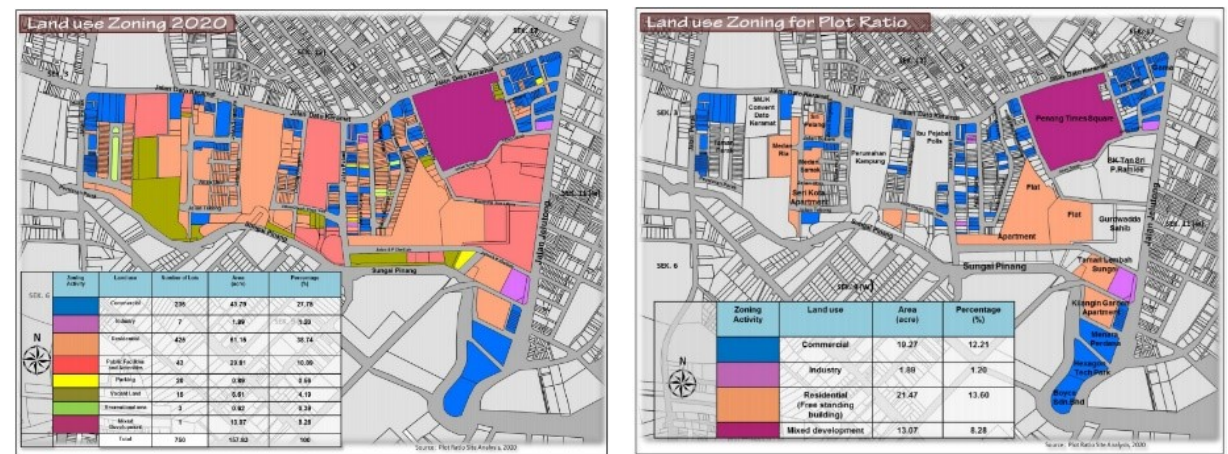

Figure 2: Methodology Flowchart Process

With a total area of 157.83 acres of the whole land use zoning in the study area, 35.29\% (55.7 acre; Commercial: 19.27, Industry: 1.89, Residential Free-Standing Building, Mixed Development: 13.07) of the land is land use of plot ratio for the study area. The area on the left is the land use area for Institution/Public Communities, Infrastructure and Utilities and Recreational Land/Open Space which have different ways of measuring the density of urban areas by using residential and population densities (Lehmann, S., 2019).
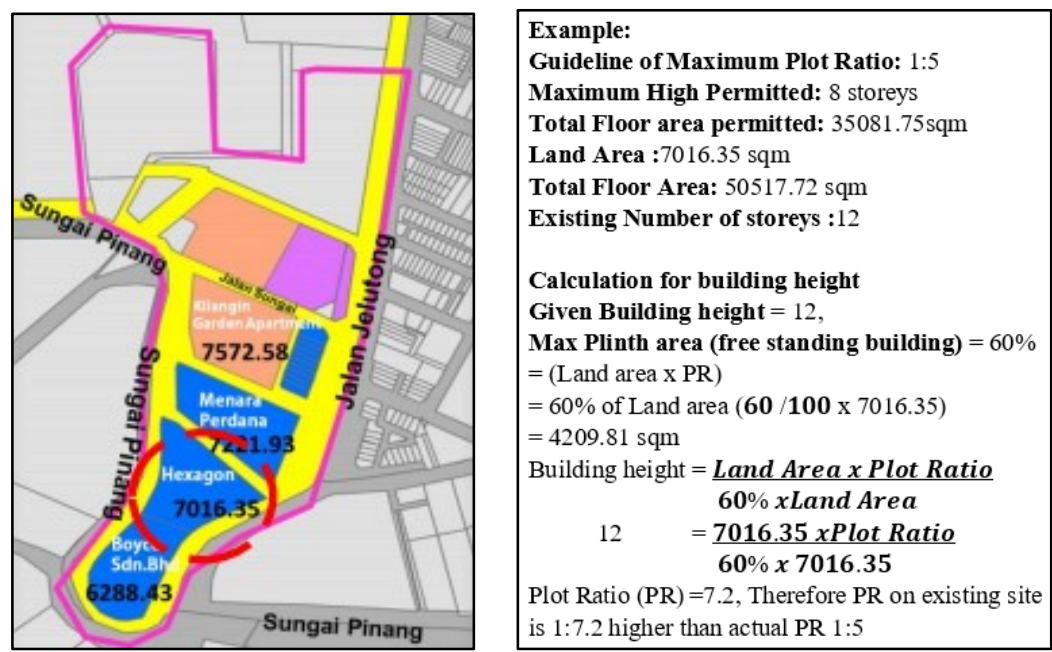

Plot Ratio $(\mathrm{PR})=7.2$, Therefore PR on existing site is 1:7.2 higher than actual PR 1:5

Figure 3: Example of Existing Plot Ratio Calculation and Site Area 

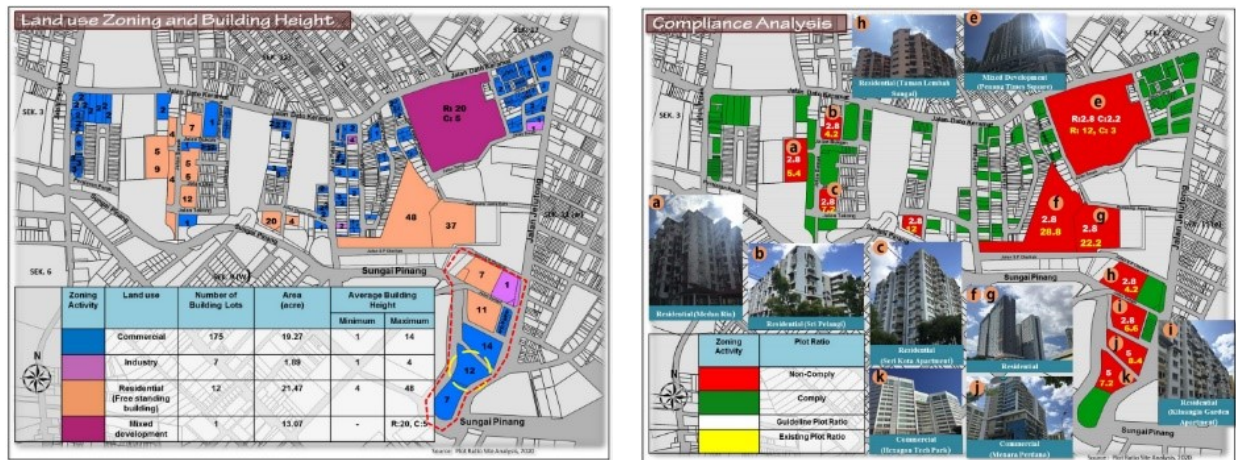

Figure 4: Compliance Analysis on Land use, Building Height and Plot Ratio.

Table 1: Statistical Number on Comparison of Plot Ratio Analysis

\begin{tabular}{|c|c|c|c|c|c|c|c|c|c|c|c|c|}
\hline \multirow[t]{2}{*}{$\begin{array}{c}\text { Zoning } \\
\text { Land Use } \\
\text { Activity }\end{array}$} & \multirow[t]{2}{*}{$\begin{array}{c}\begin{array}{c}\text { Number } \\
\text { of } \\
\text { Building }\end{array} \\
\text { Lots }\end{array}$} & \multirow[t]{2}{*}{$\begin{array}{c}\text { Area } \\
\text { (Acre) }\end{array}$} & \multirow[t]{2}{*}{$\begin{array}{l}\text { Guideline of } \\
\text { Maximum } \\
\text { Plot Ratio }\end{array}$} & \multirow[t]{2}{*}{$\begin{array}{c}\text { Guideline of } \\
\text { Maximum } \\
\text { High } \\
\text { Permitted }\end{array}$} & \multicolumn{2}{|c|}{$\begin{array}{c}\text { Existing } \\
\text { Average Plot } \\
\text { Ratio }\end{array}$} & \multicolumn{2}{|c|}{$\begin{array}{l}\text { Existing } \\
\text { Average } \\
\text { Building } \\
\text { Height }\end{array}$} & \multicolumn{2}{|c|}{ Non-Comply } & \multicolumn{2}{|c|}{ Comply } \\
\hline & & & & & Min & Max & Min & Max. & Area & $\%$ & Area & $\%$ \\
\hline Commercial & 175 & 19.27 & $1: 5$ & $\begin{array}{c}\text { Shop House: } \\
5\end{array}$ & 0.6 & 8.4 & 1 & 14 & 3.52 & 6.32 & 15.75 & 28.28 \\
\hline & & & & $\begin{array}{c}\text { Free } \\
\text { Standing } \\
\text { Building: } 8\end{array}$ & & & & & & & & \\
\hline Industry & 7 & 1.89 & $1: 5$ & 8 & 0.6 & 2.4 & 1 & 4 & - & - & 1.89 & 3.39 \\
\hline $\begin{array}{c}\text { Mixed } \\
\text { Development }\end{array}$ & 1 & 13.07 & $\begin{array}{c}1: 5 \\
\text { Residential: } \\
1: 2.8 \\
\text { Commercial } \\
1: 2.2 \\
\end{array}$ & $\begin{array}{c}\text { Residential: } \\
5 \\
\text { Commercial: } \\
4\end{array}$ & - & $\begin{array}{l}\mathrm{R}: 12 \\
\mathrm{C}: 3\end{array}$ & - & $\begin{array}{c}\mathrm{R}: 20, \\
\mathrm{C}: 5\end{array}$ & 13.07 & 23.46 & - & - \\
\hline $\begin{array}{l}\text { Residential } \\
\text { (Free } \\
\text { Standing } \\
\text { Building) }\end{array}$ & 12 & 21.47 & $1: 2.8$ & 6 & 2.4 & 28.8 & 1 & 48 & 18.47 & 33.16 & 3.0 & 5.39 \\
\hline Total & 195 & 55.7 & & & & & & & 35.06 & 62.94 & 20.64 & 37.06 \\
\hline
\end{tabular}

Table 1 shows the comparison of plot ratio analysis of existing plot ratio compliance analysis with the current land use. There are four types of land use zoning involved in plot ratio analysis, which are commercial, industry, mixed development, and residential for only free-standing buildings (FSB). Since the guidelines of plot ratio have already been identified from the planning standards and guidelines of PLANMalaysia Pulau Pinang, the existing plot ratio value that has been calculated based on mathematical calculation formula, measured, recorded are achieved. To sum it up, through the relationship of guideline plot ratio and existing plot ratio, the compliance analysis could be recognised. Ironically, from the compliance plot ratio analysis with the comparison of land use zoning, it can be overly seen that the residential land use zoning area holds the highest percentage area in that study area as well as the highest non-compliant land use zoning of plot ratio. According to Azalina et al.(2017), they stated that the high plot ratio cap on residential zones are because of the factors influenced by the owner of the land or that the person who applied for planning permission 
Syafiqah Humairah Abd Razak, Izuandi Yin

Assessment on The Implementation of Plot Ratio as A Development Control Tool in George Town, Penang

are willing to pay for the development charge due to the three reasons identified, which are conversion of land use zones, excess of floor area of the plot ratio, and excess of units above the average density residential development. Besides that, it is also supported by Kono \& Kaneko (2010), who came out to add with consideration for applicants to fulfil and provide public facilities and amenities in the land use in terms of view, recreational, and breezeways as mentioned by Abdullah et. al. (2020). The ease which people can get to important destinations using public transportation is referred to as accessibility and facilities, thus these are the attractive factors for residents to gain benefits on their property investment and also as an alternative approach for developers granting a planning permission. Hence, from the previous research study, it can be concluded that these are the main reasons on the possibility of push factors for the residential zone holding the highest value of non-compliant plot ratio in the study area. Additionally, the other factors that cause the highest non-compliance by residential area is because of the modification of the guidelines for the increase in development density from 87 units per acre to 128 units per acre on February 1, 2017 date of the enforcement for the application of these guidelines. According to news published in November 2016 by the iProperty.com.my News Team, they clarified that the authorisation of the allocation to increase the density was announced by the Chairman of the State Housing, Town and Country Committee Jagdeep Singh at the compilation, while back then before it was increased to 87 units per acre in 2010, the upper limit was 30 units per acre. Apparently, these 87 units per acre were initially supposed to be for transit-oriented planning nodes only, but developers started asking for the entire 87 units, no matter where. So, now with the allocation to increase the density to 128 units per acre, this obviously opens up opportunities for developers to apply for the maximum 128 units just for their sake of profits. The question here is whether it is fair for the developer to seek approval to submit for maximum density when many of them have been constructing homes that most ordinary Penangites could not afford.

\section{ii.The Building Conformity towards the rule of Plot Ratio}

The buildings in the study area are all following the requirements design criteria and recommendations set out in the city's spatial plan by MBPP local authority, which focuses on George Town region as a hub for linear trade and utilities. Approximately, only two types of zoning land use building plots observed are non-compliant with the rules required, which consist of residential and mixed land use development while the commercial land use all complied with the requirements in this observation segment. Therefore, this may lead to the excess of residential and mixed-use activities along Jalan Dato Keramat due to the higher intensity of development area. Such activities will lead to negative externalities, such as shortage in public services, obstruction in traffic, and carbon emissions that will influence citizens. Jalan Dato Keramat is among the worst affected 
traffic congestion areas between the Lebuhraya Thean Teik to Lebuhraya Tun Dr Lim Chong Eu along the way towards George Town city centre.

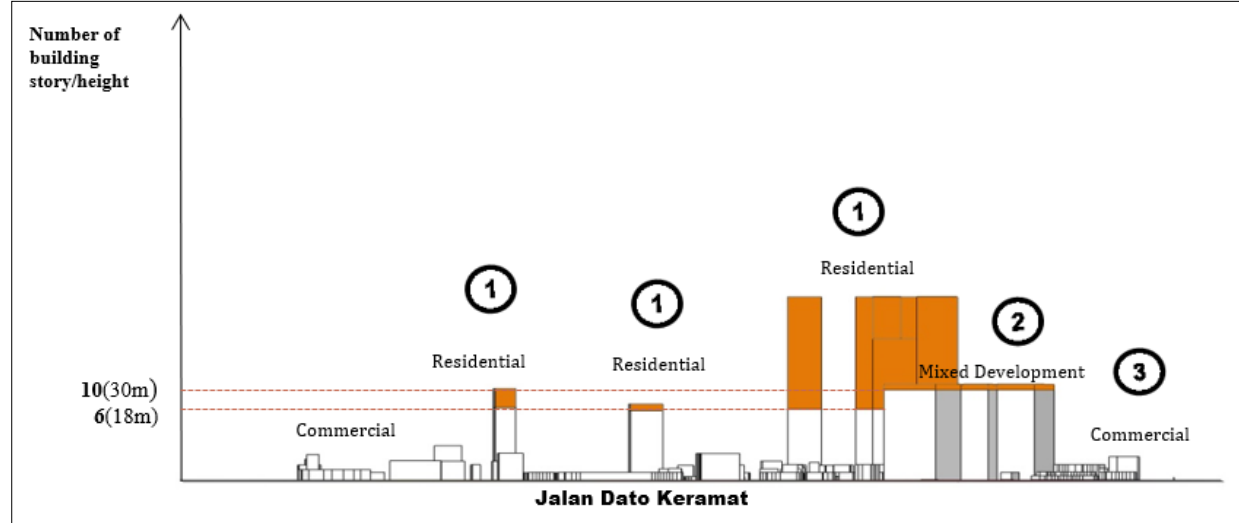

Figure 5: Skyline Simulation in Segment A

In addition, from the figure 5 of skyline simulation at segment $\mathrm{A}$, it also can be seen that the imbalance of building skyline along Jalan Dato Keramat is caused by monopoly of the residential activities that acquire a higher of building height and the maximum of plot ratio caps. Moreover, the non-compliance of guidelines by mixed land use also contributes to the increase in population density as well as increasing the demand for the limited value of real estate. This causes property prices to become very expensive because increase of development costs and property prices affected by the cost of development fee charged by the developers from the local authority due to planning permission approval.

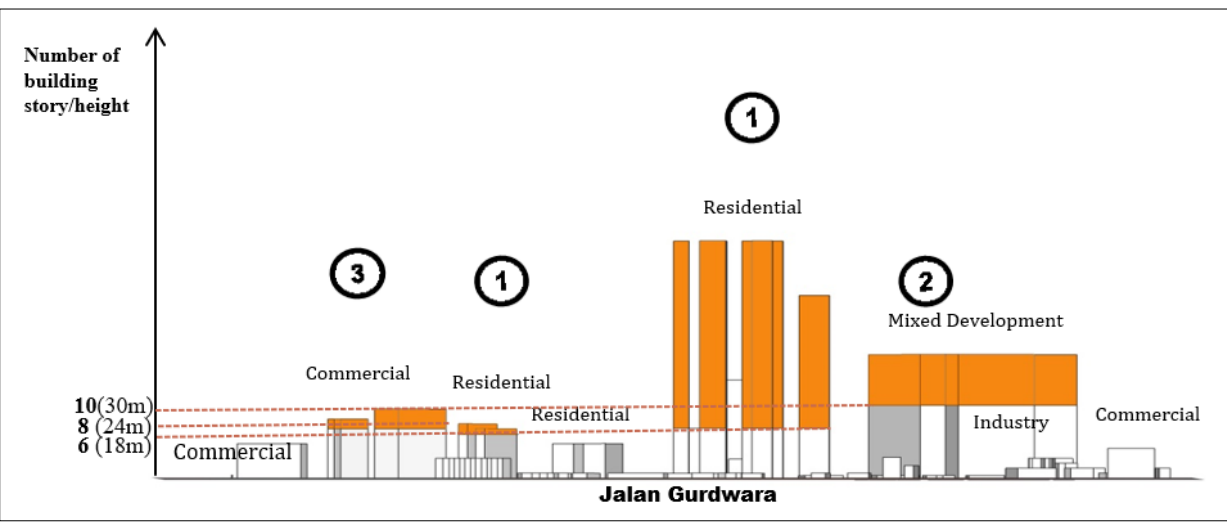

Figure 6: Skyline Simulation in Segment B 
Syafiqah Humairah Abd Razak, Izuandi Yin

Assessment on The Implementation of Plot Ratio as A Development Control Tool in George Town, Penang

Based on the field observations pictured in figure 6, three types of zoning land use building plots observed are non-compliant with the rules required which consist of commercial, residential, and mixed-land use development.

Land use distribution commercial activity in segment B were majority focused from south to north of the study area to city of George Town area. Moreover, rapid growth was observed at the centre of the study area to city of George Town area due to the higher intensity and floor space of the residential land use zoning allocation while the industry land use complied with the requirements. In addition to that, along Jalan Gurdwara, it is observed that commercial activities there are supported with the residential activities and mixed land use activities. Generally, it shows that a greater non-compliance building of plot ratio cap may cause the expanding on the growth in the city of George Town due to land use distribution, where it may lead towards the urban expansion because of the increase in number of population and traffic condition. As a result, this may contribute to the density and development trend.

\section{ACKNOWLEDGMENTS}

The authors would like to thank our main sponsor, Universiti Sains Malaysia through Short Term Grant (304/PPBGN/6315259) to avail this study. The credit also goes to all authors and School of Housing, Building and Planning, Universiti Sains Malaysia with full support to carry out the work.

\section{CONCLUSION}

Controlling the maximum plot ratio does not affect the economic viability of any future property market growth. If an alternative method is properly recorded in the planning tools, replacing with an effective policy and guidelines of plot ratio would not be harmful to the property market, instead it will bring mutual interest not only to the developers, but also to all residents for long-term harmony and sustainability of development planning. Therefore, it is recommended that plot ratios in the city and suburban areas should not be abandoned. Plot ratios have also been studied in suburban areas and it has been found that they have a role to play in protecting the integrity of the neighbourhood as well as the role and function of the city to accommodate the demands of land use activities. A more guideline-driven approach is needed followed by more processes of collective approvals. It will require a collection of fairly conservative and appropriate options in the scheme to back it up. There would also be a need for specific output criteria to support in maintaining flexibility to dispense suitable solutions. New guidelines can be drawn up with a modification of the zoning land use scheme as it currently allows appropriate solutions at present. For residential areas, it is recommended, as a priority, that residential plot ratios and density planning guidelines should be allocated a plot ratio which is equivalent with the commercial and mixed development capacity in the city areas. This takes into 
account the location and activities that demand characteristics needed to take into consideration, such as building appearance and neighbourhood characters. The recommendations will be integrated into the system to give them substantive force.

\section{REFERENCES}

Abdullah, J., Rashid, K. A., Shah, M. I. B., Leh, O. L. H., Majid, R. A., \& Ngah, R. (2020). Land Use Development and Ridership at Kelana Jaya LRT Line, Malaysia. Planning Malaysia Journal of the Malaysian Institute of Planners, Vol. 18, Issues 4, p. 220-238. November 2020. https://doi.org/10.21837/pm.v18i14.828

Azalina, N., Abdul, Y., Shaharudin, M., Ali, N., Fairuz, S., \& Pin, C. (2017). Implementation of Development Charge by Local Government of Malaysia: Implementation and Challenges. Environment-Behaviour Proceedings Journal, Vol. 2, Issues 5, p. 459. February 2017. https://doi.org/10.21834/e-bpj.v2i5.709

Bertaud, A., \& Brueckner, J. K. (2005). Analyzing Building-Height Restrictions: Predicted Impacts and Welfare Costs. Regional Science and Urban Economics. Vol. 35, Issues 2, p. 109-125, March 2005. https://doi.org/10.1016/j.regsciurbeco.2004.02.004

Deng, J. S., Wang, K., Hong, Y., \& Qi, J. G. (2009). Spatio-Temporal Dynamics and Evolution of Land Use Change and Landscape Pattern in Response to Rapid Urbanization, Landscape and Urban Planning. Vol. 92, Issues 3-4, p. 187-198, September 2009. https://doi.org/10.1016/j.landurbplan.2009.05.001

Gao, X., Asami, Y., \& Katsumata, W. (2006). Evaluating Land-Use Restrictions Concerning the Floor Area Ratio of Lots. Environment and Planning C: Government and Policy, Vol. 24, Issues 4, p. 515-532. August 2016. https://doi.org/10.1068/c0531

Hamdan Abdul Majeed (2012). Urban Regeneration: The Case of Penang, Malaysia Putting Policy into Practice. Khazanah Nasional. World Bank. pp. 117. April 2012. Retrieved from https://web.archive.org/web/20160104014144/http:/siteresources.worldbank.org/ INTCHD/Resources/430063-1310571283698/MalaysiaBBL2.pdf

Izuandi Yin, Mou Leong Tan, Tew Yi Lin, Diana Mohamad, Abdul Ghapar Othman (2019). Monitoring Land Use Pattern and Built-Up Expansion in Kuala Lumpur City Centre, ICRP 2019, 4th International Conference on Rebuilding Place. The European Proceedings of Multidisciplinary Sciences, Vol. 2, p. 200-214, December 2019, eISSN: 2421-826X, https://doi.org/10.15405/epms.2019.12.20.

Izuandi Yin and Jamalunlaili Abdullah (2020), The Development Control of Urban Centre in Kuala Lumpur, Malaysia, Planning Malaysia Journal of the Malaysian Institute of Planners, Vol. 18, Issues 3, p. 313-325. July 2020. http://dx.doi.org/10.21837/pm.v18i13.795

Joshi, K. K., \& Kono, T. (2009). Optimization of Floor Area Ratio Regulation In A Growing City. Regional Science and Urban Economics, Vol. 39, Issue 4, p. 502511, July 2009. https://doi.org/10.1016/j.regsciurbeco.2009.02.001 
Syafiqah Humairah Abd Razak, Izuandi Yin

Assessment on The Implementation of Plot Ratio as A Development Control Tool in George Town, Penang

Kono, T., \& Kaneko, T. (2010). Necessity of Minimum Floor Area Ratio Regulation: A Second-Best Policy. The Annals of Regional Science, Vol. 44, p. 523-539. 2010. https://doi.org/10.1007/s00168-008-0269-0

Lehmann, S. (2019). Density. The Wiley Blackwell Encyclopedia of Urban and Regional Studies. April 2019. https://doi.org/10.1002/9781118568446.eurs0074

Lai, S., \& Ooi, C. (2015). Branded as a World Heritage City: The Politics Afterwards. Place Branding and Public Diplomacy, Vol. 11, p. 276-292, November 2015. https://doi.org/10.1057/pb.2015.12

Narimah, M. A. M. (2019). Impact of Urban Development to The Communities In George Town Conurbation. European Proceedings of Social and Behavioural Sciences EpSBS, Future Academy, Article 8, Vol. 68, p. 749-759. September 2019. https://doi.org/10.15405/epsbs.2019.09.81

Samat, N., Ghazali, S., Hasni, R., \& Elhadary, Y. (2014). Urban Expansion and Its Impact on Local Communities: A Case Study of Seberang Perai, Penang Malaysia, Pertanika Journal of Social Science and Humanities, Vol. 22 Issue 2, p. 349-367. June 2014. Retrived from https://www.researchgate.net/publication/286163365_Urban_expansion_and its impact_on_local_communities_A_case_study_of_Seberang_Perai_Penang_Ma laysia

World Bank Group, Khazanah Nasional \& EPU (2015). Achieving a System of Competitive Cities in Malaysia Main Report. Economic Planning Unit, Prime Minister's Department, Malaysia. November 2015. Retrieved from http://documents1.worldbank.org/curated/en/709061475743434007/pdf/102222v1-REVISED-PUBLIC-Malaysia-Competitive-Cities-Main-Report-low-resfinal.pdf

Received: $4^{\text {th }}$ January 2021. Accepted: $25^{\text {th }}$ April 2021 